\title{
İstanbul'daki Kent İçi Köprülerin Estetik Açıdan İncelenmesi
}

\author{
Ferhat Pakdamar \\ Gebze Teknik Üniversitesi \\ ORCID-0000-0002-5594-3095
}

\author{
Cahide Aydın İpekçi \\ Gebze Teknik Üniversitesi \\ ORCID-0000-0003-3170-4628
}

\section{Öz}

Bu çalışmada, kent içi karayolu üzerindeki köprüler (üst geçit, alt geçit) estetik bağlamda ele alınmıştır. Çalışma kapsamında ulaşım yoğunluğunun fazla olduğu kentlerin başında gelen İstanbul İli örneklem alanı olarak seçilmiştir. Kent içi köprülerin bir başka deyişle yaya ve taşıtın birlikte kullandığı köprülerin estetik açıdan incelenmesi amacıyla hazırlanan bu çalışma, taşıyıcı sistem malzemesi betonarme olan köprüler ile sinırlandırılmıştır. Incelenen köprülerde tasarım aşamasinda sadece yönetmeliklere uygun fakat estetik olmayan detaylar içeren projelerin üretilmeye başlandığı, eski köprünün yanına yapılan köprülerde eski-yeni yapı uyumunun göz ardı edildiği saptanmıştır. Bakım onarım çalışmaları sırasında çeoreyle uyum gözetilmeksizin renkli boyalar kullanılmış, reklam içerikli panoların da bu tür köprülerde kullanımının giderek arttı̆̆g gözlenmiştir. Kent içi köprülerin özellikle İstanbul gibi metropollerde tasarmm aşamasından itibaren estetik unsur gözetilerek yapılabilmesi için ilgili yönetmeliklerde gerekli düzenlemelerin yapılması ve bu konuyla ilgili olarak oluşturulacak estetik komisyonlarının işlevselliğinin önemini vurgulamak da bu çalışmanın amaçlarından biridir. Bu nedenle çalışmada ele alınan kent içi köprü uygulamalarında görülen sorunların incelenmesi, yeni yapılacak köprülerin tasarım ve projelendirme aşamalarn için önem arz etmektedir. İncelenen çok sayıda köprü arasından seçilen örneklere ait bilgiler tabloda ifade edilmiş, her birinde görülen estetik kusurlar fotoğraflarla birlikte detaylı olarak anlatılmış ve çıkarımlar sonuç olarak özetlenmiştir.

Anahtar Kelimeler: Kent içi köprü, köprü estetiği, estetik, üst geçit, alt geçit 


\title{
Aesthetic Review of Urban Bridges in Istanbul
}

*

\author{
Ferhat Pakdamar \\ Gebze Technical University \\ ORCID-0000-0002-5594-3095
}

\author{
Cahide Aydın İpekçi \\ Gebze Technical University \\ ORCID-0000-0003-3170-4628
}

\begin{abstract}
In this study, bridges (overpass, underpass) over the land route which have an important place in transportation, are tackled. The province of Istanbul, which is the highest concentration of transportation in the study, was chosen as the sampling area. This study, which was prepared in order to examine urban bridges, in other words bridges used by pedestrians and vehicles in terms of aesthetics, is limited to bridges which are reinforced concrete bearing system material. In the design phase, projects that are only in compliance with the regulations but contain non-aesthetic details have begun to be produced, the old-new building harmony was ignored in the bridges built next to the old bridge. During maintenance and repair work, colored paints were used without regard to environmental compliance, it has also been observed that the use of advertisement-based panels in such bridges is increasing. In order to make urban bridges especially in metropolises such as İstanbul by taking into account the aesthetic elements from the design stage, necessary arrangements in the related regulations, regarding this, it is also one of the aims of this work to show importance of aesthetic commissions have become to work. Therefore, it is important to examine the problems in urban bridge applications which are discussed in the study, for to design and to project stages of new bridges. The information about the selected examples among the dozens of bridges examined in the light of the mentioned reasons, expressed on the table, the aesthetic defects seen for each are explained in detail together with the photographs separately and the inferences are summarized as a result.
\end{abstract}

Keywords: Urban bridges, bridge aesthetics, aesthetics, underpass, overpass. 


\section{Giriş}

Yaşadığımız çağda nüfus bakımından Avrupa'nın büyük şehirlerinin başında gelen İstanbul metropolünün önemli sorunları arasında göçe bağlı hızlı, plansız kentleşme, kent imar planları ve ulaşım planlarındaki düzensizliklerin getirdiği trafik sorunu bulunmaktadır. Bununla birlikte İstanbul'da mevcut otomobil sahipliliği 2023 öngörülerinde 275/1000 kişi olacağı hesaplanmıştır (Akı ve Öztaş, 2015, s.52). Bu da mevcut karayolu ağının artan otomobil bağımlılığına koşut olarak karayolu ağının da artırılmasını gerektirecektir. Dünyadaki ulaşım trendlerine benzer bir eğilim gösteren İstanbul' da da artan motorlu taşıtlar ve trafik talebini karşılamak üzere yapılan yollara ek olarak kent içi köprülerinin sayısının artacağı anlamina gelmektedir.

Bu nedenle örneklem alanı olarak seçilen İstanbul'daki kent içi köprü uygulamalarında gözlemlenen sorunların ele alındığı bu çalışmada, estetik unsurların da yer alacağı bir "köprü yönetmeliği" nin gerekliliği konusuna dikkat çekilmek amaçlanmıştır. Bununla birlikte bu çalışmayla estetik komisyonların işler hale gelmesinin ne kadar önemli bir konu olduğunu göstermek de hedeflenmiştir. Bu bağlamda çalışmada ele alınan kent içi köprülerde görülen sorunların incelenmesi aşaması, kent peyzaj1nın birer parçası olan köprülerin, tasarım ve projelendirmesinde yeni yapılacak köprüler için önem arz etmektedir.

\section{Araştırma Yöntemi}

Çalışma kapsamında ulaşım yoğunluğunun fazla olduğu İstanbul D100 karayolu, 2. Çevreyolu ve bağlantı yolları üzerindeki betonarme köprüler arasından seçilen 17 adet örnek için veriler tablolaştırılmış, köprü estetiği bağlamında fotoğraflar ve saha çalışmaları üzerinden ayrı ayrı incelemeler gerçekleştirilmiş ve uzman görüşü ile birlikte sunulmuştur.

\section{Kent İçi Köprüler ve Estetik Sorunu}

İlk çağlardan itibaren insanoğlu farklı gereksinimler doğrultusunda ki bunlardan ilki olan "barınma" amacıyla üst örtü oluşturma ya da açıklık geçme gibi çeşitli problemleri çözme konusunda çalışmalar sürdürmekte- 
dir. İnsanlı̆̆ın gelişim sürecinde, insanoğlunun doğa etkilerinden korunma çabası kadar, yerçekimini yenme, ona karşı koyma, direnme uğraş1sı da devam etmektedir (Türkçü, 1997, s.9).

Birbirinden engellerle ayrılmış doğal ya da yapay parçaları "köprü" ile birleştirmek açılık geçme problemlerinden biridir. İnsanoğlu tarihin ilk dönemlerinden beri doğadaki engelleri aşma çabası ile bir yakayı diğer yakaya, kimi zaman ise bir kıtayı diğer kıtaya bağlamak için köprüler tasarlamıştır. Engelleri aşma çabasının en güzel örnekleri ve yaşamımızın ayrılmaz bir parçası olan köprülerin ilk örnekleri nehir üzerine devrilmiş bir ağaç ya da üzerinden geçilen su içindeki kaya parçaları olarak düşünülebilir. Sonrasında sarmaşık, asma ağacı gibi doğal malzemelerin bükülebilen kısımlarından, doğal liflerle yapılan halatlarla geniş açıklıklar üzerinden geçilen sistemlerin, asma köprülerin geliştiği görülmektedir.

Köprü; kelime anlamı olarak Ansiklopedik Mimarlık Sözlüğünde “(i) aralarında su, çukur arazi veya yol gibi engeller bulunan iki yakayı birbirine bağlayarak yolu bir yandan ötekine eriştirmek için yapılan ahşap, kâgir veya madeni yapı; (ii) iki binayı veya bir binanın iki parçasını birbirine bağlayan geçit" şeklinde tanımlanmaktadır (Hasol, 1995, s.273).

Orta Asya'da eski Türk dilinde bugünkü ‘köprü' kelimesinin karşılığ olarak; 'köpür', 'köpr-üg' kelimeleri kullanılmış, Uygurca metinlerde Kaşgari, 'köprüg', sonra Osmanlıca'da İbn-ül-Muhanna ile Ebu Hayyam 'köprü' diye yazmıştır. Türkmence 'köpri', Çağatayca 'köprük', Tatarca 'köbrük', Azerice 'köprü" olarak, benzer biçimlerde Türkçe ve komşu dillere yerleşmiştir. Türkçe'de 'köprüg' veya 'kobrug' kelimesi, çeşitli Avrupa dillerinde, 'brug', 'brig', 'brücke', 'bridge' olarak kullanılmaktadır (Sütiçen, 2008, s.6).

Geçecek yer veya iki yapıyı birbirine bağlayan üstü örtülü yol anlamına gelen "geçit" kavramı ise, doğal zemin altındaki yaya veya taşıt geçidi alt geçit; doğal zeminin üstündeki yaya veya taşıt geçidi ise üst geçit olmak üzere ikiye ayrılmaktadır (Hasol, 1995, s.33). İşlevsel açıdan bakıldığında, köprü bir geçit yani bir yerden diğerine gitmeyi olanaklı kılan bir ulaşım öğesi, bölgesel ölçekte bir sirkülasyon elemanıdır. Üst geçit/köprü akrabalığının kaynağı da budur (Şahin, 1983, s.10).

Coğrafi bakımdan çeşitli zorlukların (akarsu, engebeli arazi, vadi vb.) bir arada bulunduğu araziler üzerindeki uygarlıklar için ulaşımı sağlayan stratejik yapıların başında köprüler gelmektedir. Köprü inşaatı sadece ticari açıdan değil hem siyasi-askeri nedenlerle çok kritik, hem de devletle- 
rin varlığı ve genişleme politikaları ile her daim doğrudan ilişkili olmuştur (Binan, 2006, s.182). Köprüler ile ilgili en eski yazılı belge, Herodot'un söz ettiği ve M.Ö.8. yy'da Furat Nehri üzerinde inşa edilmiş olan Babil'deki köprüye ilişkindir (Başdoğan ve Manisa, 2016). Anadolu' da izleri bulunabilmiş en eski köprünün tarihi ise, Hitit döneminde M.Ö.13. yy'a kadar inmekte olup, Boğazköy'de taş malzeme kullanılarak bindirme tekniği ile yapılmıştır (Binan, 2006, s.182).

Dünyanın farklı coğrafi bölgelerinde farklı işlevlerde (su kemerleri vb.) gerçekleştirilen ilk köprülerde, geçilecek açıklık için ister bir nehir, akarsu, isterse bir vadi olsun doğada var olan ahşap, taş vb. doğal malzeme kullanılmış, teknik ve teknolojinin gelişimi ile köprü yapımında kullanılan malzemeler de farklılaşmıştır. 18.yy'da Endüstri Devrimi ile birlikte demir ve çeliğin kullanımının yaygınlaşması modern anlamda köprü yapımının da başlangıcını oluşturmuştur. Bu dönemde inşa edilen köprülerde malzeme seçiminde ilk olarak demir, sonraları çelik, beton ve betonarme kullanılmıştır. Zamanla gerek üzerinden geçen taşıtların çeşitliliği gerekse aşılması gereken engellerin büyüklüğü; köprü yapımının mühendislik ve teknolojik açıdan sürekli gelişmesine yol açmıştır. Bu dönemde köprüler daha çok mühendisliğin ilgi alanına girmiş, mimarlar açısından estetik bir ürün olmanın ötesine geçemediği görülmüş̧ür. Yakın zamana kadar köprüler; ayak aralığı, yükseklik, uzunluk vb. teknik özellikleri ile gündeme gelmiştir (Başdoğan ve Manisa, 2016, s.56).

Günümüzde kent merkezlerinde karayolu, raylı sistemler gibi yoğun trafik akışı içinde yayaların rahat hareket edebilmeleri ve trafik akışının düzenlenmesi amacıyla kent içi köprüler yapılmaktadır. Ancak, gerek yapıldığ yer ile ilgili planlama sürecinde ortaya çıkan sorunların yeterince çözümlenememesi, gerekse köprü kullanımında tasarım aşamasında ön görülemeyen problemler ile köprülerin kent içi trafiğinde yayalara pek çok sıkıntı yaşamasına neden olduğu gözlemlenmektedir.

Kentlerde artan nüfus ve hızlı kentleşme ile değişen öncelikler sonucunda tüm dünyada olduğu gibi ülkemiz kent trafiğindeki araç sayısı da artış göstermekte ve gün geçtikçe ulaşım daha karmaşık bir duruma gelmektedir. Özellikle su kıyısı veya su ile iç içe olan ve değişken eğimli topografya üzerinde yer alan İstanbul gibi megakentlerin farklı bölgelerinin birbirine bağlanma gereksinimi artmaktadır. Başta metropoliten alanlarda olmak üzere, kentlerde farklı bölgeler arasında yaya ve taşıt geçişi de artan trafik talebinin karşılanmasında yaşanan güçlüklerle beraber giderek zorlaşmaya başlamıştır. Buna çözüm olarak yapılan köprüler/üst geçitler 
bugün bir kent ögesi haline gelmiştir. Hızla gelişen yüksek teknoloji ve malzeme özellikleri sayesinde kentlerde, inşa edilen köprülerin kent trafiği ve ekonomisindeki önemi giderek artmaktadır. Taşıyıcı sistemi, malzemesi ve yapım tekniği ile olduğu kadar estetiği ile de kentte önemli bir yere sahip olan kent içi köprülerin, kentlinin hayatında güvenli ve konforlu bir geçiş imkânı sağlaması gerekmektedir. Kentlerimizin mekânsal örgütlenmesinde, trafiği yoğun caddelerin üzerinde artan sayıda üst geçit inşaatları ile görece küçük, ama etkin (şehircilik terimiyle) kentsel donatım elemanının getirdiği değişiklikler görülmektedir. Köprü, çok anlamlılık taşıyan bir mekânsal örtü, üst geçit ise köprüden oldukça farklı olarak "kentsel sirkülasyon" bir "kentsel donatım elemanı" olarak okunabilmektedir (Şahin, 1983, s.10)

Sayısı gün geçtikçe artan kent içi köprüler; yer tercihleri, işlevsel hatalar ve kentin tarihsel/estetik görünüşüne etkisi gibi noktalarda odaklaşan eleştirileri de beraberinde getirmektedir. Üst geçit de köprü gibi iki bölgeyi birleştiren bir yapıdır. Ancak, aşılan engel, bir doğa biçimi değil, yapay bir kentsel mekân elemanı olan cadde olgusuna dönüşmüş, böylece üst geçidin işlevi yaya veya taşıt ulaşımı olmuştur. Yaya ve taşıt trafiğinin birbirleriyle kesişmesini önleyen bir düzenlemeyi oluşturmak üzere bir araya getirilen bu iki ulaşım biçimi -yaya ulaşımı ve taşıt ulaşımı- arasında, ulaşım işlevinin/ulaşımın engellenmesi terimleriyle beliren ve hızla derinleşen çelişki, çağdaş kentin çözümlenmesi gereken önemli sorunlarından biri halini almıştır (Şahin, 1983, s.10).

Ülkemizde ana yol güzergâhlarında kent içinde yer alan köprülerin estetik olarak planlaması konusunda farklı başarı düzeyinde çok sayıda örneğe rastlamak mümkündür. Köprüye biçimini kazandıran en temel faktör açıllğın/engelin geçilmesi için seçilen taşıyıcı sistemdir. Taşıyıcı sistemi oluşturan elemanların doğru oranlarda düzenlenmesinde çevreyle uyumuna ve peyzaj içindeki yerleşimine dikkat edilmesi köprülere estetik bir form kazandırılması açısından önemlidir. Ayrıca köprü formunun yanı sıra kullanılan malzeme, renk, boya, doku, dekoratif unsurlar ve güvenlik de tasarımda ihmal edilmemesi gereken köprü bileşenleridir. Ancak ülkemizdeki köprü uygulamalarında dikkate alınacak veya uyulacak Karayolları Genel Müdürlüğü (KGM) tarafından 1982 yılında basılan "Yol Köprüleri İçin Teknik Şartname" adlı çok sınırlı bilgi içeren küçük bir kitapçık dışında hali hazırda herhangi bir "köprü yönetmeliği" bulunmamaktadır. Bu nedenle şimdiye kadar yapılan köprülerde kamu kurumları, tasarımclardan Amerikan Köprü Yönetme- 
liği'ne (AASHTO Bridge Design Specification) uygun olarak çözüm üretmelerini istemiştir (AASHTO, 2014). Her ne kadar AASHTO en iyi yönetmeliklerden biri olsa da estetik konusundaki yaptırımlarının yetersiz oluşu nedeniyle 2009 yılında başlanan "Bridge Aesthetics Sourcebook" (Sourcebook, 2010) çalışması sonucunda 2012 yılında AASHTO yönetmeliğine estetik ile ilgili Tasarım Hedefleri Başlığı altında "2.5.5. Bridge Aesthetics" maddesi eklenmiştir. Buna ilaveten "Design guidelines to improve the appearance of bridges in NSW" (Bridge Aesthetics, 2003) ismiyle Avusturalya New South Wales bölgesi için hazırlanan ve oldukça iyi bir köprü estetiği rehber yönergesi mevcuttur. "Toplumsal bellek bireysel bir yeti değildir ve içinde bulunulan toplumsal koşullar tarafından belirlenmektedir" (Assmann ve Tekin, 2001, s.44; Avcıŏglu ve Akın, 2017, s.423; Halbwachs, 1992, s.37-38) düşüncesi çok iyi anlaşılamamış olsa gerektir ki Türkiye'de üzerinde yeterince durulmadığı ve estetik konusunun genellikle göz ardı edildiği görülmektedir.

Yine Erkartal (2016, s.498)'ın “Kent, oluştukları dönemin kültürünü, sosyal yapısını, estetik kaygıların ve yapım teknolojilerini yansıtan mimari katmanlardan oluşmaktadır." cümlesinden çok uzak bir anlayışla estetikten yoksun, mühendislik odaklı tasarımların sadece emniyet ve ekonomi öncelikli köprülerin yapımına devam edilmektedir. Bu nedenle mimari estetik komisyonlarının estetik kurulla karıştırılmaması gerekmektedir. Mimari estetik komisyonları 03.07.2017 günlü Resmi Gazetede yayımlanan 30113 sayılı Planlı Alanlar İmar Yönetmeliği ${ }^{1}$ Altıncı Bölüm Madde 66'da (ÇŞB, 2017) yeniden düzenlenmiştir. Yönetmeliğe göre mimari estetik komisyonunun, organize sanayi bölgeleri hariç, ilgili diğer idareler bünyesinde kurulması ve beş uzmandan oluşması zorunludur. Uzmanlık alanları; en az biri mimar olmak üzere inşaat mühendisi, peyzaj mimarı, sanat tarihçisi, şehir plancısı ve harita mühendisinden oluşmalıdır (Ünal, 2017, s.23). Mimari estetik komisyonlarının işlevselliği yeni yapılacak kent içi köprülerde doğru tasarımın bir parçası olan estetiğin başarılı bir şekilde uygulanabilirliği açısından önem arz etmektedir.

\section{Kent İçi Köprü Uygulamalarında Bulgular Üzerinden Estetik Unsurların İncelenmesi}

Geniş açıklıkların geçilmesinde doğal bir engeli aşmak ya da bir trafik akımının başka bir trafik akımını kesmeden geçmesini sağlamak için ulaşımda önemli bir yeri olan kent içi köprüler (yaya ve taşıt üst geçitleri) 
sadece geçilen açıklık ve taşıyıcı sistemi ile değil, mimari estetiği, tekniği, malzemesi, biçimi, aydınlatmasıyla da çevreye uyumlu olarak tasarlanmalıdır. Proje aşamasında kullanılan malzemelerin detaylandırılması kullanım sonrası oluşabilecek problemlere karşı çözüm üretilmesinde yardımcı olacaktır. Kullanım aşamasında boyama, darbe, parçaların sökülmesi gibi eylemler, köprülerin kullanımını olumsuz yönde etkilemekte ya da kesintiye uğratmaktadır. Asılan afişler, flamalar ve aydınlatma elemanları köprülerin estetik görünüşünü bozmakta ayrıca taşıt kullanıcılarının dikkatini dağıtıcı etkisi bulunmaktadır.

Çalışma kapsamında incelenen 17 adet betonarme köprü Karayolları Bölge Müdürlüğü (KBM) tarafından verilen adları parantez içinde belirtilerek numaralandırılmış, köprülere ait genel bilgiler inşa yılına göre sıralanarak Tablo 1'de verilmiştir, her biri çalışmanın ana omurgasını oluşturan "estetik köprü" unsurları açısından fotoğraflar üzerinde ayrı ayrı incelenmiştir.

K1 köprüsü (Fotoğraf 1.a-b) kurpta ${ }^{2}$ köprülerin yerinde dökme tabliye ile imalinin ne kadar estetik bir görüntü çıkardığı, orta ayak kalınlığının kenarlara doğru azaltılarak zarif gösterilmeye çalışıldığı güzel örneklerden biridir. Kalıp işçiliğindeki özensizliğin, betonarme yapıya yansıması görülmektedir. 1969 yılında yapılan köprünün hala faal durumda bulunması ve yakın geçmişte yapılan köprülere nazaran daha zarif olması dikkate değer bir unsurdur.

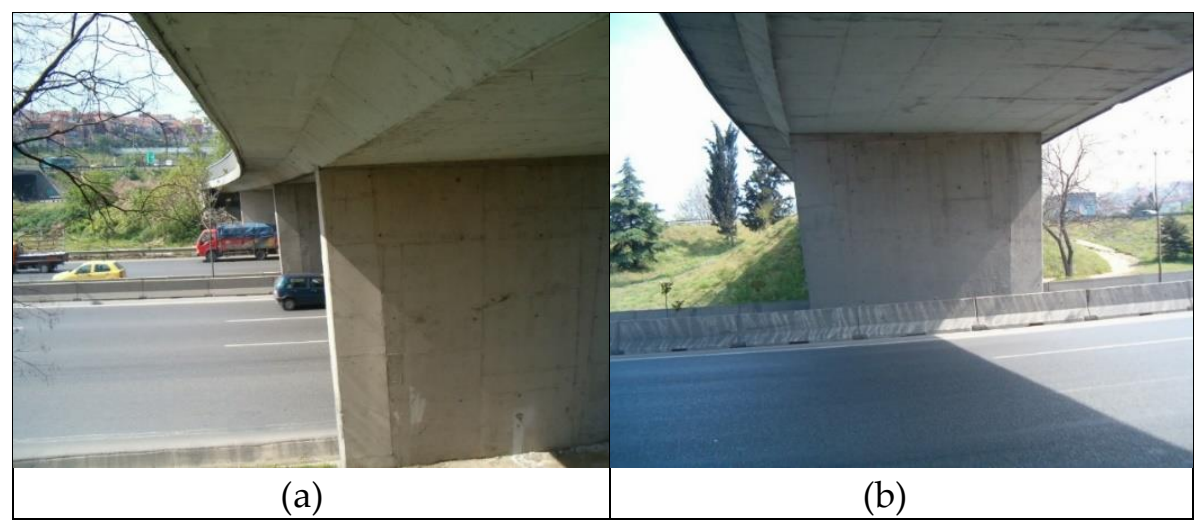

Fotoğraf 1. K1 Köprüsü, 2006 (Kaynak: F. Pakdamar) 
Tablo 1. İncelenen kent içi köprülere ait genel bilgiler

\begin{tabular}{|c|c|c|c|c|c|c|c|c|c|}
\hline $\begin{array}{l}\text { Köprü No } \\
\text { (KBM Adı) }\end{array}$ & 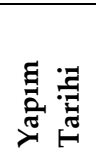 & $\begin{array}{l}\widehat{\Xi} \\
\text { ते } \\
0\end{array}$ & 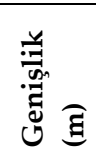 & 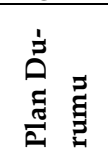 & 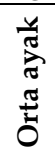 & 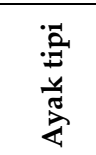 & $\frac{y}{z}$ & 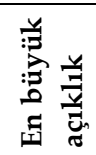 & 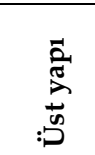 \\
\hline K1 (K510) & 1969 & 65.90 & 10.50 & Kurpta & 3 & Perde & 4 & 19.80 & Plak \\
\hline K2 (K102) & 1970 & 71.00 & 9.70 & Düz & 3 & Perde & 4 & 20.50 & Plak \\
\hline K3 (K207) & 1970 & 68.80 & 11.50 & Düz & 3 & Perde & 4 & 19.90 & Plak \\
\hline K4 (K303) & 1971 & 73.30 & 9.50 & Kurpta & 2 & Kolon & 3 & 30.80 & $\begin{array}{c}\text { Sandik } \\
\text { Kesit }\end{array}$ \\
\hline K5 (K204) & 1971 & 34.00 & 16.50 & Düz & 1 & Perde & 2 & 17.00 & Plak \\
\hline K6 (İkitelli) & $\begin{array}{l}1970- \\
1980 \\
\end{array}$ & 67.40 & 27.00 & Düz & 4 & Perde & 5 & 14.60 & Plak \\
\hline K7 (M301) & $\begin{array}{l}1980- \\
1990\end{array}$ & 111.5 & 14.50 & Düz & 3 & Perde & 4 & 31.10 & $\begin{array}{c}\text { Trapez } \\
\text { Kiriş }\end{array}$ \\
\hline K8 (B13) & 1987 & 44.00 & 14.00 & Düz & 1 & Perde & 2 & 22.00 & $\begin{array}{c}\text { Trapez } \\
\text { Kiriş }\end{array}$ \\
\hline K9 (B6 eski) & 1998 & 45.50 & 14.00 & Düz & 1 & Perde & 2 & 22.80 & $\begin{array}{c}\text { Trapez } \\
\text { Kiriş } \\
\end{array}$ \\
\hline K10 (M501) & $\begin{array}{l}1980- \\
1990\end{array}$ & 86.70 & 18.50 & Düz & 2 & Perde & 3 & 21.60 & I Kiriş \\
\hline $\begin{array}{l}\text { K11 } \\
\text { (Sefaköy eski) }\end{array}$ & 1990 & 53.10 & 9.00 & Düz & 3 & Perde & 4 & 14.60 & Plak \\
\hline $\begin{array}{l}\text { K12 } \\
\text { (Askeri Saha) }\end{array}$ & 1994 & 73.00 & 14.00 & Düz & 2 & Perde & 3 & 25.00 & I Kiriş \\
\hline $\begin{array}{l}\text { K13 (İmar- } \\
\text { yolu) }\end{array}$ & 1995 & 36.50 & 15.50 & Düz & 1 & Perde & 2 & 18.20 & I Kiriş \\
\hline $\begin{array}{l}\text { K14 } \\
\text { (Sefaköy Yeni) }\end{array}$ & 1998 & 53.20 & 9.70 & Düz & 3 & Perde & 4 & 14.60 & I Kiriş \\
\hline K15 (UK147) & $\begin{array}{l}1990- \\
2000 \\
\end{array}$ & 52.10 & 9.10 & Düz & 1 & Perde & 2 & 26.05 & $\begin{array}{c}\text { Trapez } \\
\text { Kiriş } \\
\end{array}$ \\
\hline $\begin{array}{l}\text { K16 } \\
\text { (B6 Yeni) }\end{array}$ & $\begin{array}{l}2000- \\
2017\end{array}$ & 45.50 & 14.00 & Düz & 1 & Perde & 2 & 22.80 & I Kiriş \\
\hline $\begin{array}{l}\text { K17 (Mahmut- } \\
\text { bey yeni) }\end{array}$ & $\begin{array}{l}2010- \\
2017 \\
\end{array}$ & 145.4 & 13.00 & Düz & 3 & Perde & 4 & 30.00 & I Kiriş \\
\hline
\end{tabular}

K2 köprüsü (Fotoğraf 2.a-b) 1970 yılında yapılmış olup 1970-1980 arası yapılan köprülerin ilk örneklerindendir. Köprü tabliyesi "ard germe" betonarme tabliye olduğu için geçtiği açıklığa oranla oldukça incedir. Yol genişliği sebebiyle üst tabliyeyi taşıyan orta ayaklar, yekpare perde beton yerine 3 eşit parçaya bölünerek tasarlanmıştır. Aşağıdan yukarıya artan, değişken bir kesit kullanılarak orta ayaklara estetik bir görüntü kazand1rılmıştır. Bu tip köprülere eski adıyla E-5 yeni adıyla D100 karayolu üzerinde sıklıkla rastlanmaktadır. Tabliye kenarındaki konsola "guse" havasının katılması, "fasya" nın döşeme kenarını ölçülü bir şekilde kapatması 
ve bunun ötesinde her kalıp köşesinin mutlaka 45 derece kalıp çıtası ile yumuşatılmış olarak büyük ve pürüzsüz kalıp işçiliği ile yapılmış olması, bu köprülerin yapıldığı dönemde estetik kaygılar taşıyan mühendis ve mimarların bulunduğunun en güzel göstergeleridir.

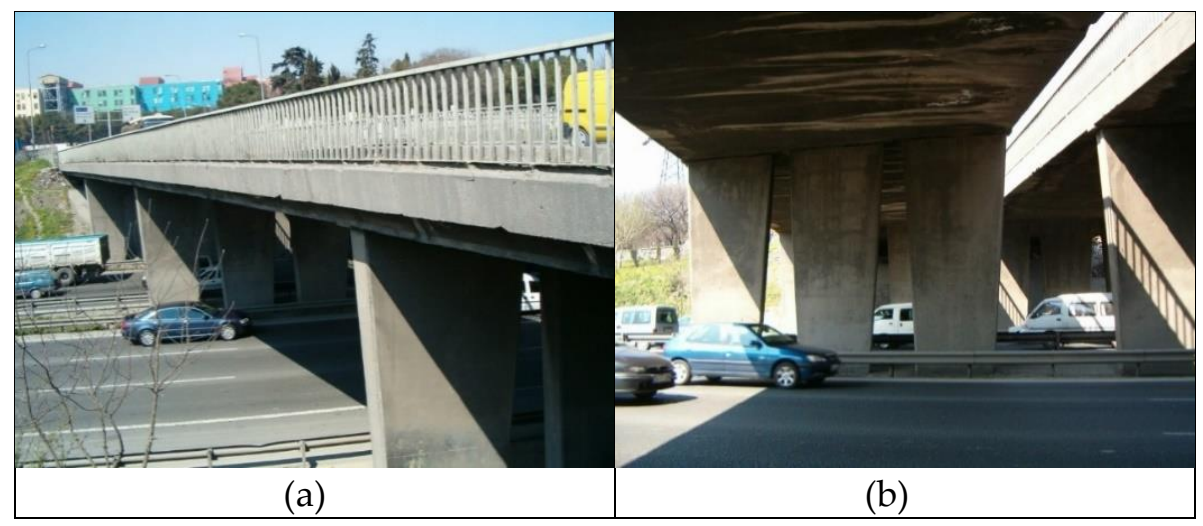

Fotoğraf 2. K2 Köprüsü, 2006 (Kaynak: F. Pakdamar)

K3 köprüsü (Fotoğraf 3) 1970-1980 arası yapılan köprülere diğer bir örnektir. Üst tabliye genişliği fazla olmadığı için orta ayağı yekpare perde olarak teşkil edilmiş olup aşağıdan yukarıya doğru eğim verilerek estetik bir görüntü kazandırılmıştır. Yıpranmış olmasına rağmen uygun fasya kullanımı ve özenli işçilikle yapıldığı görülmektedir.

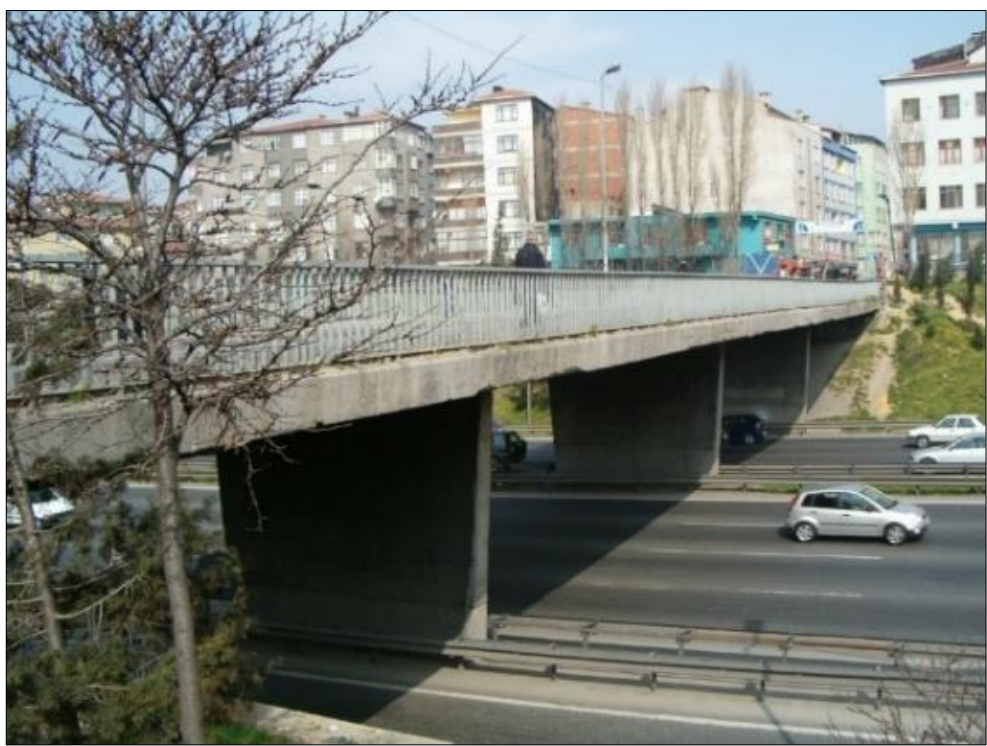

Fotoğraf 3. K3 Köprüsü, 2006 (Kaynak: F. Pakdamar) 


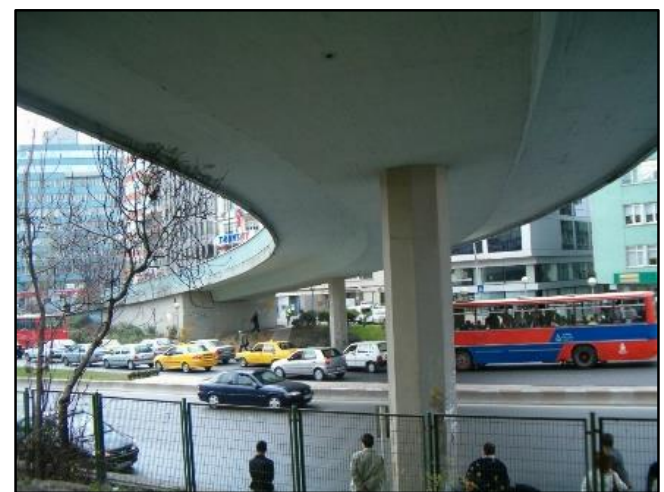

1971 yılında yapılan K4 köprüsünün tabliyesi ard germeli, iki orta ayaklı ve kurbta olarak tasarlanmıştır (Fotoğraf 4). Ard germeli sandık kesiti, çok zarif duran sekizgen şeklindeki orta ayakları ve uygun fasyası ile kente oldukça estetik bir görüntü vermektedir.

Fotoğraf 4. K4 Köprüsü, 2006 (Kaynak: F. Pakdamar)

1971 yılında yapılan K5 köprüsü (Fotoğraf 5) K2 ile benzer teknik ve estetik özelliklere sahiptir. Ancak köprüye asılan bir reklam panosunun durumu ayrıca tartışılması gereken bir husustur. Çünkü estetik olarak her ne kadar hoş görünmese de yüksek getirisi nedeniyle bu reklam panolarından vazgeçilememektedir. Afişlerin görünümü (tasarım ve renklerin belirlenmesi) ve kent silüetine etkisini değerlendirecek bir estetik komisyonun değerlendirmesine gereksinim olduğu görülmektedir. Afişlerin estetik komisyon onayından geçerek uygulanması üzerinde önemle durulması gereken bir husustur.

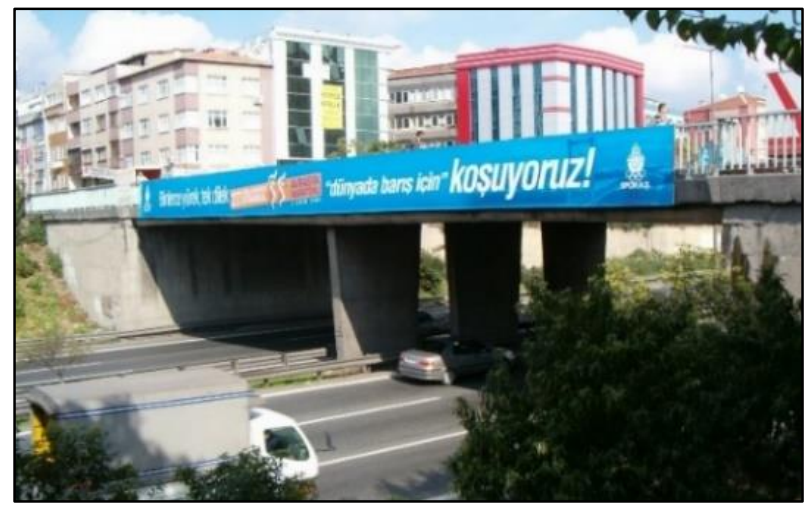

Şekil 5. K5 Köprüsü, 2006 (Kaynak: F. Pakdamar)

1970-1980 yılları arasında yapılan köprülerin son zaman örneklerinde işçilik bozulması veya tasarımcının bu konuda detay vermemesi K6 Köprüsü'nde açıç̧a görülmektedir (Fotoğraf 6.a-b). Dönemin tasarım felsefesi 
açısından estetik görünümde olmasında rağmen uygulama evresinde sorunludur, inşa aşamasında yeterli özen gösterilmemiştir. Tasarımcı tarafından uygulamaya yönelik olarak perde ayakların yüzey dokusu ile ilgili bir detay öngörülmemiş olması nedeniyle, yapım sonrası ortaya çıkan betonarme kalıp izleri kötü bir doku oluşturmuştur.

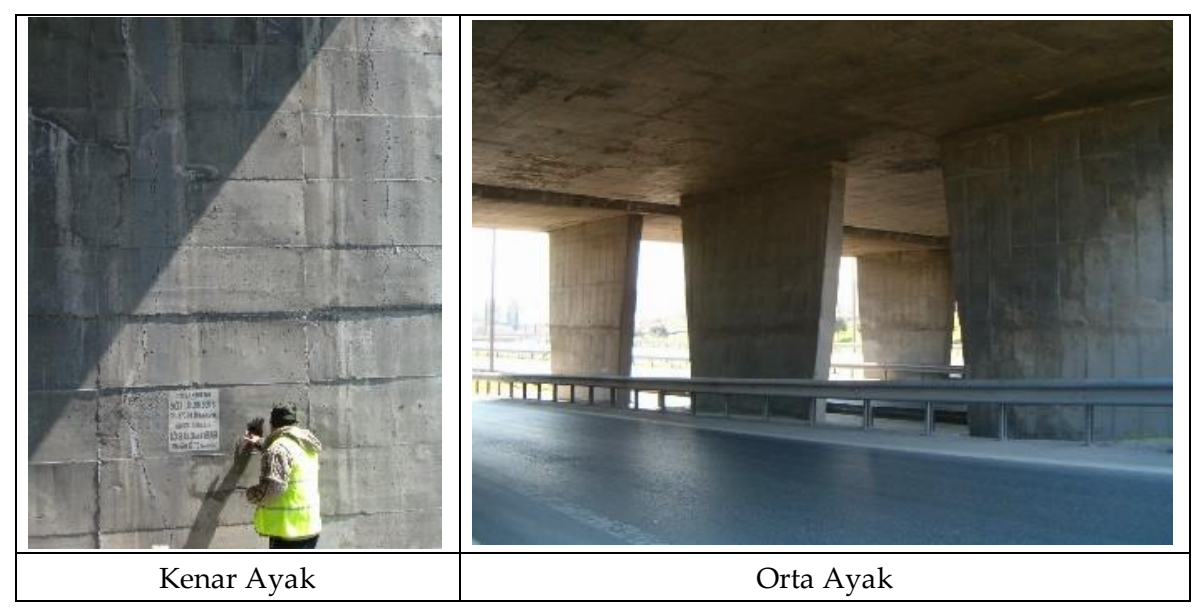

Fotoğraf 6. K6 Köprüsü, 2006 (Kaynak: F. Pakdamar)

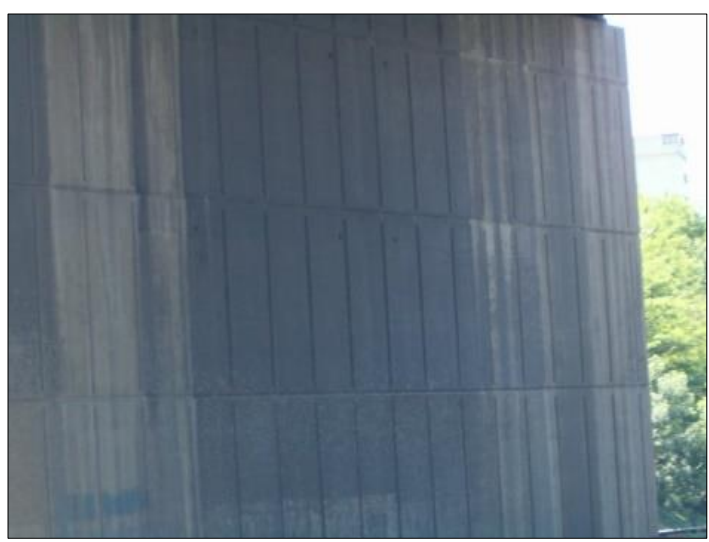

1980-1990 y1lları arası yapılan Fotoğraf 7.'de kenar ayağı görülen K7 adlı köprü, kalıp çıtası ile doku verme estetik gayretinin çok büyük yüzeyler için monoton hale gelmesinin engellenemediği bir köprü örneğidir. Ancak K6 Köprüsü ile kıyaslad1ğında kalıp izleri ve işçiliği açısından daha iyi bir uygulama olduğu söylenebilir.

Fotoğraf 7. K7 Köprüsü, 2006 (Kaynak: F. Pakdamar) 


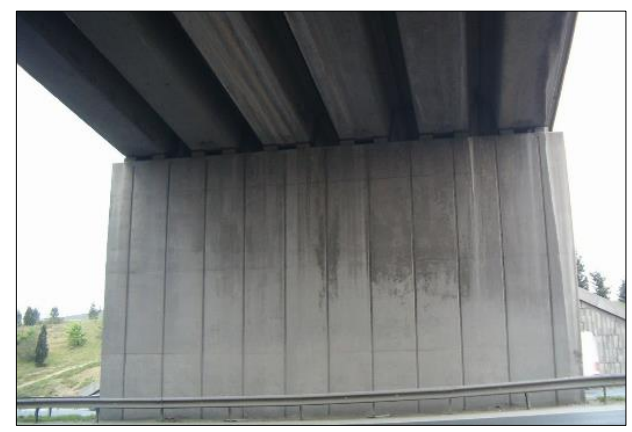

K8 Köprüsü'nde (Fotoğraf 8) ise yekpare betonarme orta ayak kalıbının estetik kaygı güdülerek çıtalı olarak teşkil edilmesi ile monoton olan yüzey dokulu hale getirilmeye çalışılmıştır. 19701990 arası yapılan pek çok köprüde bu desen tüm ayak yüksekliğinde görülmektedir.

Fotoğraf 8. K8 Köprüsü, 2006 (Kaynak: F. Pakdamar)

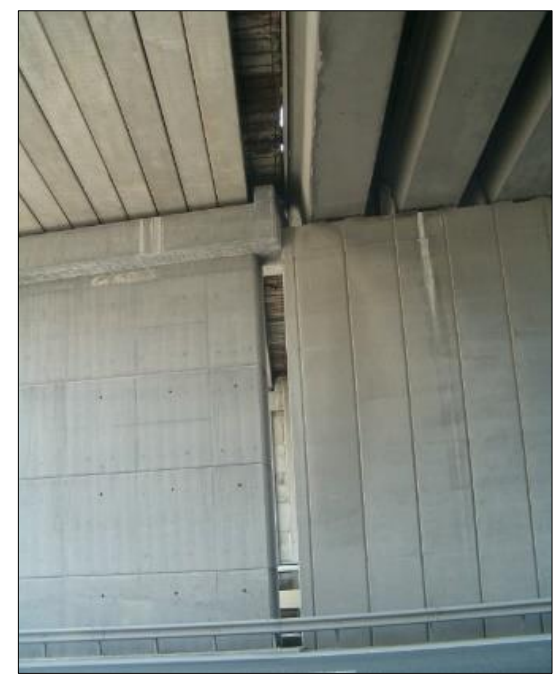

İstanbul Avrupa Yakası Gazi Osman Paşa İlçesi O-2 (E80) Otoyolu üzerinde bulunan K9 Köprüsü'nün (Fotoğraf 9) sağ tarafında bulunan orta ayak 1988 yılında yapılan eski köprüye, sol tarafında bulunan orta ayak ise 2000-2017 arası yapılan yeni köprüye aittir. Eski köprü trapez (omega) kesit kiriş ve perde orta ayaklı sistemle imal edilmiştir. Yeni köprü ise I kesitli boyuna kiriş, perde orta ayak ve üzerinde başlık kirişi ile teşkil edilmiştir.

Fotoğraf 9. K9 (sağda, eski) ve K16 (solda, yeni) Köprüleri, 2006 (Kaynak: F. Pakdamar)

Farklı dönemlerde yapılmış bu köprülerin boyuna kirişler için yönetmeliklerin ön gördüğü oturma mesafeleri de farklılık göstermektedir. Bu nedenle yeni köprünün estetik kaygı gözetmeden üretildiği söylenebilir. Ayrıca yeni köprünün başlık kirişi enine takoz çıkıntısı yönetmelik gereğince tasarlanmıştır, fakat daha zarif çözümler teknik olarak mümkündür (Fotoğraf 10). 


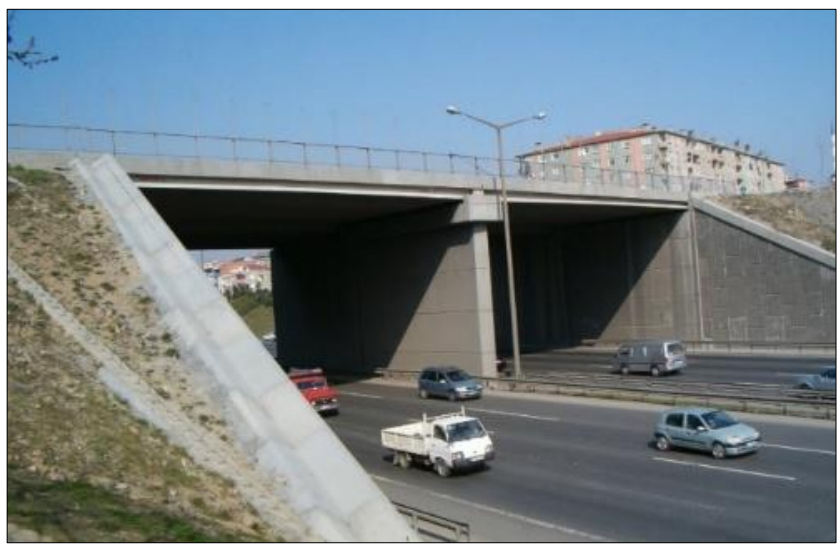

Fotoğraf 10. K16 Köprüsünde başlık kirişinin hem boyuna hem enine taşması durumu, 2006 (Kaynak: F. Pakdamar)

Ümraniye' de 1990'lı yıllarda O-2 Otoyolu üzerinde yapılmış olan K10 köprüsü (Fotoğraf 11) yönetmeliğe uygun fakat estetik kaygıdan yoksun tasarımın ilk örneklerindendir. Deprem takozu orta ayak perdesine guseli olarak eklendiğinden orta ayağın dışına taşmıştır. Estetik olmayan bu çözüm ilerleyen yıllarda daha da kötüye gitmiştir. Bu duruma örnek olarak K16 Köprüsünde (Fotoğraf 10) görüldüğ ü üzere başlık kirişi olmadan orta ayaklara yönetmeliklerde belirtilen oturma boyu talebine bağlı olarak estetik olarak inceleme yapmadan, ilave başlık kirişleri konulmuştur.

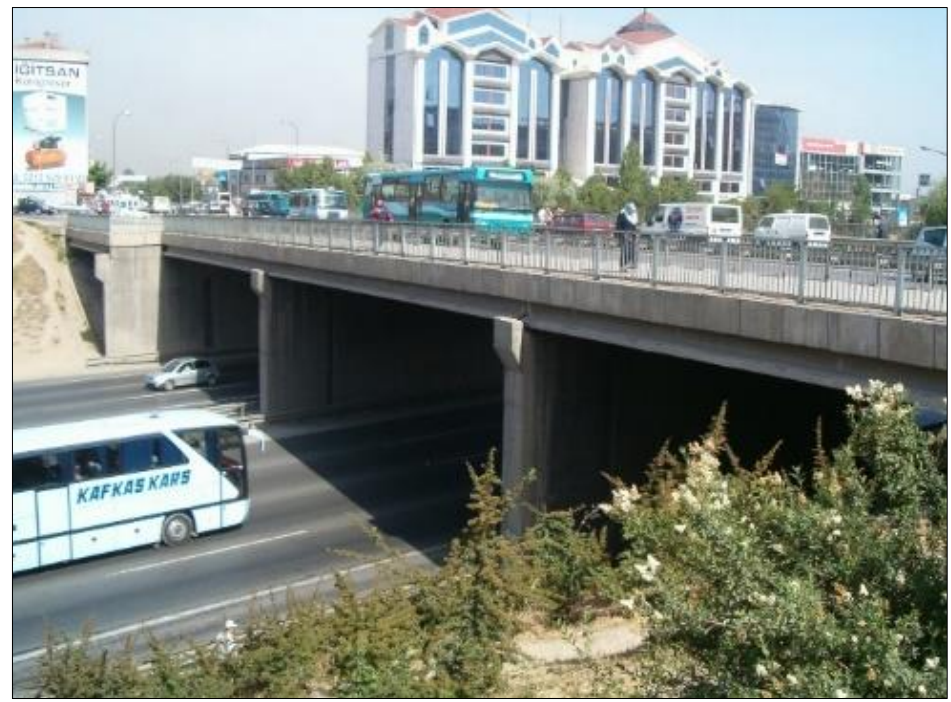

Fotoğraf 11. K10 Köprüsü, 2006 (Kaynak: F. Pakdamar) 
K11 eski (1990) ve K14 yeni (1998) köprülerine bakıldığında ise 1990'ların başına kadar estetik tabliye ve daralan orta ayaklı köprüler uygulanmaktayken (Fotoğraf 12. sağ eski), 1990'lardan günümüze kadar olan süreçte ise fotoğrafın sol tarafında görülen orta ve kenar ayaklar arasına boyuna prefabrik kirişlerin konulması ile teşkil edilen bir nevi lego türü köprüler uygulanmıştır. Lego köprülerin hızlı imal edilebilmesi ve ekonomik olması, maalesef estetik kaygının kaybedilmesine yol açmıştır. K14 yeni köprüsünde yanındaki eski köprüye özenilerek orta ayakta eğim yapılması estetiğin son çırpınışlarıdır. Benzer şekilde, K17 Köprüsü'nde de (Fotoğraf 16) görüleceği üzere orta ayakta boyuna ve enine doğrultuda incelme ortadan kalkmıştır.

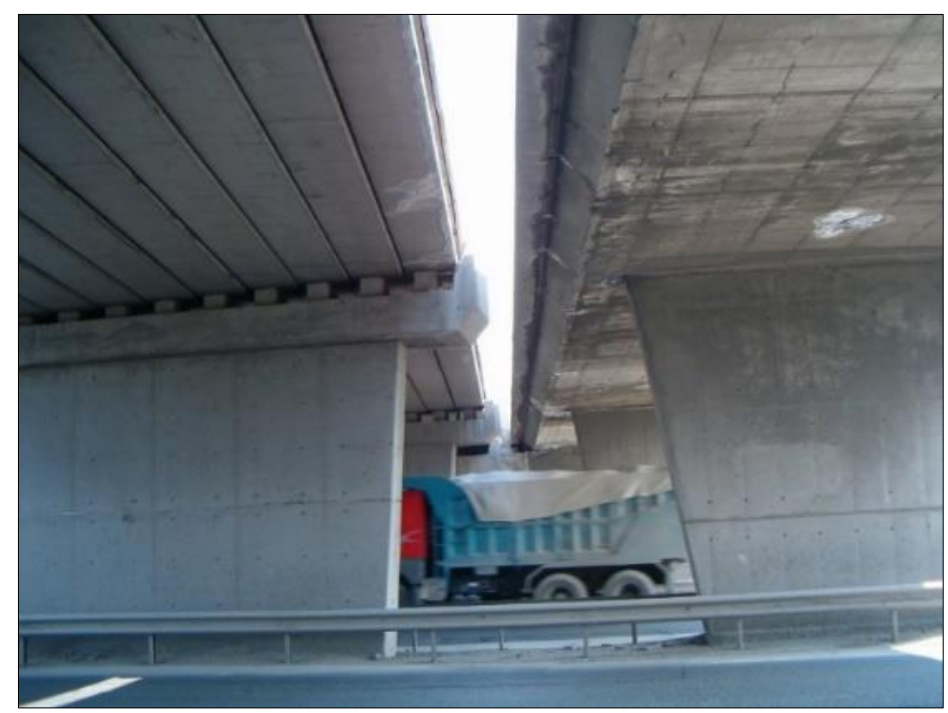

Fotoğraf 12. K11 (sağda, eski) ve K14 (solda, yeni) Köprüleri, 2006 (Kaynak: F. Pakdamar)

1980-1990 yılları arası yapılan kent içi köprülerde boyuna açıklıklar ilk örneklere kıyasla döşeme ile değil prefabrik I kirişle geçilmeye başlanmıştır. 1994 yılında Esenler İlçesi'nde inşa edilmiş olan K12 Köprüsü I kirişli köprülere bir örnektir (Fotoğraf 13). Orta ayak ve kenar ayakların aynı hat üzerine imal edilmeye çalışılması, orta ayakların yekpare perde beton olarak teşkil edilmesi, perde kalıp izlerindeki çıta izlerinin yönlerinde birlik 
olması bir estetik kaygı varlığını sergilemektedir. Fakat daha sonraki yıllarda daha çok belirginleşecek olan boyuna kiriş yan oyuklarının (Fotoğraf 13-14) kütleyi bozan çizgisi bu yıllarda ortaya çıkmaya başlamıştır.

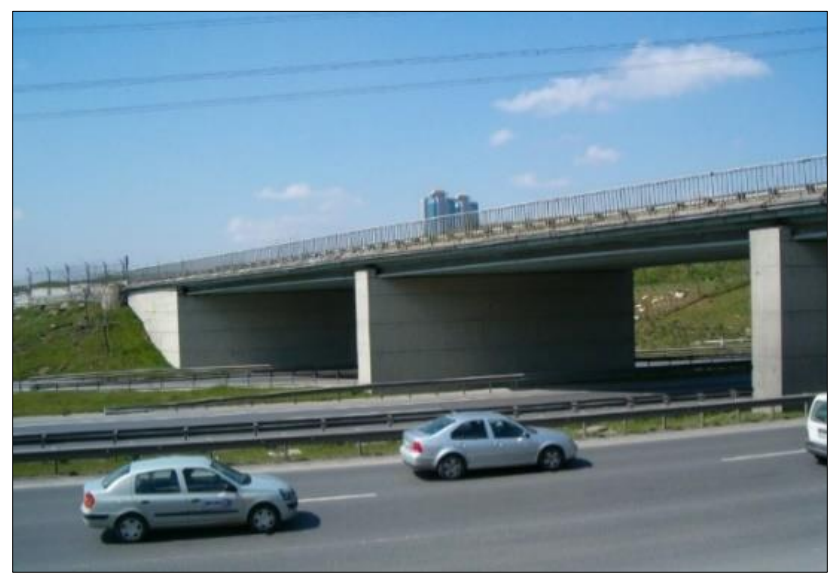

Fotoğraf 13. K12 Köprüsü, 2006 (Kaynak: F. Pakdamar)

Fotograf 13 ve 14'de görüldüğü üzere fasya uygulaması yerine, tabliye kenarı, kenar ayaklar ve orta ayak aynı hizaya gelecek şekilde bütüncül bir çizgi sergilenmiştir. 1980'li yıllara kadar yapılan köprülere göre kaba sayılabilecek ancak günümüzdeki uygulamalara kıyasla estetik bir görüntüye sahiptir. Fotoğraf 14.'de görülen K13 Köprüsü de aynı özelliklere sahip diğer bir örnektir.

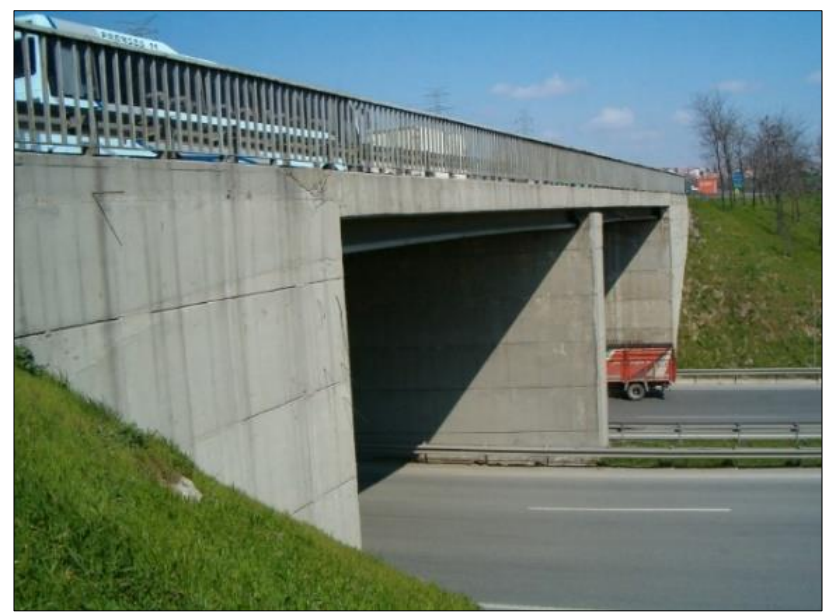

Fotoğraf 14. K13 Köprüsü, 2006 (Kaynak: F. Pakdamar) 
Anadolu Otoyolu (Fatih Sultan Mehmet Köprüsü ve çevre yolu) üzerinde oldukça standart olarak üretilmiş pek çok kent içi köprü Fotoğraf 15.'de görülen K15 köprüsü şeklindedir. Köprünün genel olarak oranları, fasya kullanımı, orta ayak ebat ve kalıp derzleri birbirleriyle uyum içinde tasarlanmıştır. Köprü boyuna kirişlerinde tercih edilen trapez (omega) kesitli kiriş yerine I kesit kullanılsaydı yan verevliklerdeki ahenk de elde edilemezdi. Uyum olarak gözden kaçırılan tek noktanın orta ayak üzerinde yer alan boyuna kirişlerin birleşme hizasında açıklık olması nedeniyle görüntüde köprü hattının tam yansıtılamamasıdır. Ayrıca orta ayaktaki kalınlık ve bunu estetik olarak rahatlatma kaygısının olmayışı da diğer bir olumsuz tarafıdır.

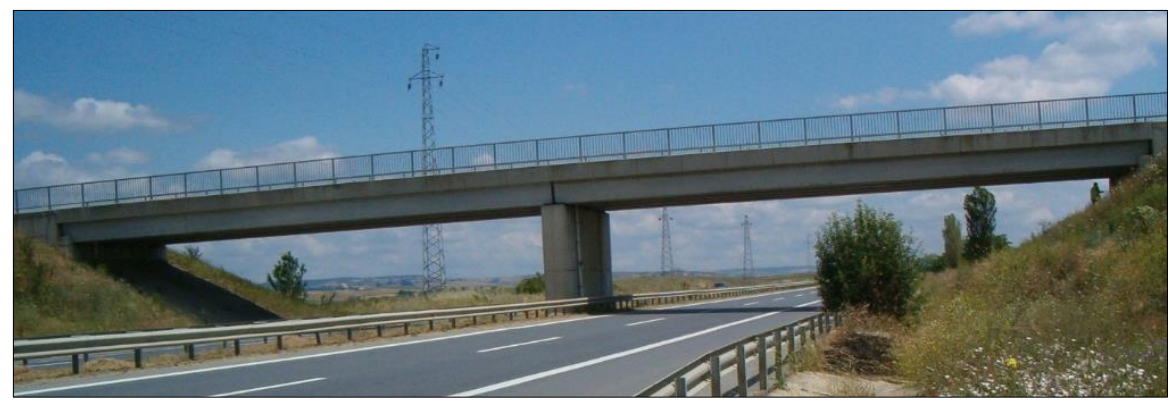

Fotoğraf 15. K15 Köprüsü, 2006 (Kaynak: F. Pakdamar)

2000 yılı ve sonrasında imal edilen üst geçit köprülerin şeklini temsil eden K17 Köprüsü (Fotoğraf 16) örneğinde görüldügü üzere; dörtgensel ve dik orta ayaklar, yumuşatılmamış köşeler, kolonun üstünden dışarı fırlamış başlık kirişi konsolları ve başlık kirişi üzerinde estetik durmayan deprem takozu bulunmaktadır. Bu tür köprülerde boyuna I kirişlerin yan oyuklarının örtülmeye çalışılmaması ve açık bırakılması, fasyanın sadece döşeme kenarını kapatacak şekilde yetersiz uygulanması diğer estetik olmayan noktalardır. 


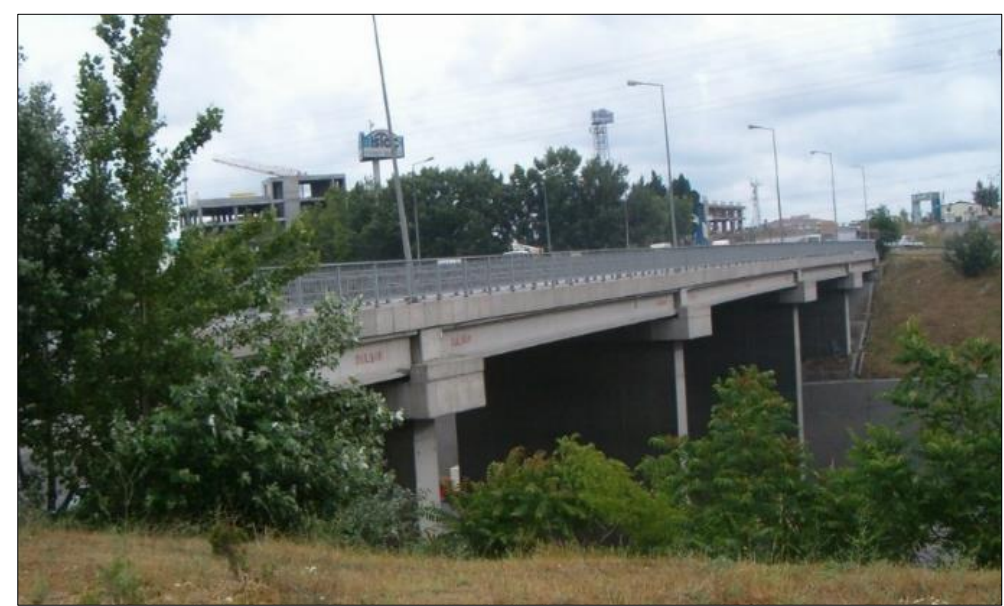

Şekil 16. K17 Köprüsü, 2006 (Kaynak: F. Pakdamar)

Ayrıca köprüde verevlik varken orta ayaklar ile köprü hattının bu verevliğe uygun olmayan bir başlık kirişi ve deprem takozu ile çözülmüş olması ortaya isimlendirilemeyecek bir geometrik şeklin çıkmasına sebep olmuştur (Fotoğraf 17.a). Yağmur suyu tahliye boruları da isimlendirilemeyen bu geometrik şekilli deprem takozunun üzerinden ve açıktan indirilmesi de köprü tasarımında görsel niteliklere dikkat edilmediğini yansıtan en iyi örnektir (Fotoğraf 17.b).

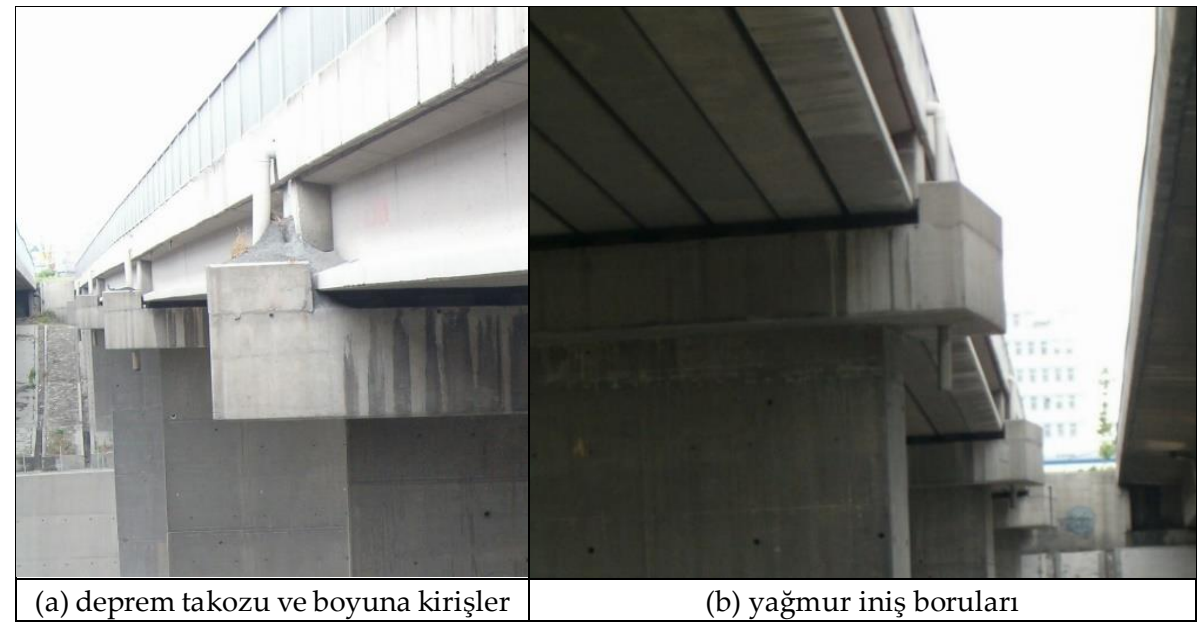

Fotoğraf 17. K17 Köprüsü, 2006 (Kaynak: F. Pakdamar) 


\section{Değerlendirme ve Sonuç}

Ülkemizde kent merkezlerindeki trafiği rahatlatma amacıyla yapılan planlama çalışmalarında taşıt trafiği çözümünün birinci planda ele alındığı söylenebilir. Bu amaçla yapılan alt ve üst geçitler kesintisiz bir ulaşım sağlamalarından dolayı trafiği de hızlandırmaktadır.

Kent içi köprü ihtiyacının gerçekten gerekli olduğu durumlarda, belirli sayıdaki insanı ve taşıtı bir noktadan diğerine ulaştıracak olan köprüler/üst geçitler sadece mimari estetiği değil, tekniği, malzemesi, biçimi ve aydınlatmasıyla da çevreye uyum göstermelidir. Köprü yapım yerinin kararı ile başlayan planlama süreci, ulaşım yaklaşımı, çevre ilişkileri ve yönetmelikler çerçevesinde köprünün tasarlanması ve uygulanması ile son bulmaktadır. Kent içi köprü (üst geçit) uygulamalarında görülen sorunların incelenmesi yeni yapılacak köprülerin tasarım ve projelendirme aşamaları için oldukça önem arz etmektedir.

Ulaşım yoğunluğunun fazla olduğu İstanbul'da, D100 karayolu ve 2. Çevreyolu ve bağlantı yolları üzerinde yer alan betonarme köprüler arasından seçilen örnekler, kent estetiği bağlamında mimari ve teknik açıdan incelenmiştir. Bu örneklerde aynı konumdaki farklı tarihlerde yapılmış eski-yeni köprü uyumsuzluğu, köprü ayaklarında kalıp izleri, başlık kirişi konsol çıkıntısı (boyuna), başlık kirişi takoz çıııntısı (enine), boyuna kiriş yan görüntüsünün gizlenmemesi, yetersiz fasya, köprü verevliği ile orta ayaklar ve başlık kirişi çıkıntısının uyumsuzluğu, orta ayak kalınlığının inceltilmemiş olması, reklam panosu, boya, renk uyumu, yağmur iniş boruları düzeni gibi çeşitli estetik unsurlar dikkate değer bulunmuş, incelemeler sonucunda görülen hatalar aşağıda özetlenmiştir;

- K1, K2, K3, K4 ve K5 köprülerinde eski ile yeni köprünün birbirleri ile uyumlu yapılmasına özen gösterilmiş,

- K9, K10, K12 ve K13 köprülerinde, boyuna kirişin yan görüntüsü gizlenmeyerek görsellikten uzaklaşılmış,

- K10, K12, K13, K14 ve K17 köprülerinde yetersiz fasya uygulanmış,

- Başlık kirişi takoz çıkıntısı (enine), K12 ve K13 köprülerinde makul ölçülerdeyken K16, K10, K14 ve K17 köprülerinde ise yanlış yapılmıştır. Ayrıca K14 ve K17 köprülerinde başlık kirişi konsol çıkıntıları da boyuna yapılmış, K17 köprüsünde yağmur iniş boruları da doğru şekilde çözülmediğinden hoş olmayan bir görüntü ortaya çıkmış, 
- K1 köprüsünde köprü ayaklarındaki kalıp izleri K6 köprüsüne nazaran daha makul seviyede,

- K8 ve K15 köprülerinde ise orta ayak kalınlığının köprüye uygun bir oranda olmaması, $K 5$ köprüsünde ise reklam panosu köprüyle uyumsuz bir görüntüye neden olmuştur.

Sonuç olarak;

- 1969-2017 arası incelenen örneklerde; köprülerde uygulanan estetik unsurların ve dolayısıyla estetik tasarım kaygısının zamana göre ters orantılı olarak değiştiği, olumsuzlukların arttığı görülmüştür.

- Söz konusu örneklem alanında incelenen 17 adet köprüden en zarif kent içi köprülerin 1969-1980 yılları arasında yapılanlar olduğu anlaşılmıştır.

- Son zamanlarda gerçekleştirilen uygulamalarda zarif köprülerle karşlaşılmaması, estetik probleminin mühendis, mimar ve idarenin inisiyatifine bırakıldığının, herhangi bir kanun ve kuralın olmadığının, estetik bir yaptırımın yasayla öngörülmediğinin göstergesidir.

- Köprü uygulamalarında yasal yaptırımlar ve estetik komisyon olmadığı için emniyet ve ekonomi öncelikli olarak düşünüldüğü estetik unsurların kesinlikle göz ardı edildiği, estetik ve ekoloji gibi değerleri göz önünde bulundurmayan tasarımın yaygınlaştığı görülmüştür.

- Mevcut yönetmeliklerde estetik yaptırımın olmadığı, en iyi yönetmelik olarak görülen Amerikan Köprü Yönetmeliği'nde (AASHTO Bridge Design Specification) dahi küçücük bir bölüm olarak konulduğu saptanmıştır.

- Köprülere asılan reklam afişlerinin görüntüsünü (tasarım ve renklerin belirlenmesini) ve kentin silüetine etkisini değerlendirecek bir mimari estetik komisyon onayına gereksinim olduğu anlaşılmıştır.

- Köprü ve çevresindeki reklam panosu ve afişlerin, aydınlatma ve drenaj sistemleri gibi silüeti etkileyecek her uygulamanin mutlaka mimari estetik komisyon onayı ile yapılması uygun olacaktır.

- Bir seçenek olarak mimari estetik komisyon onayından geçen alternatifler, anketler, dijital platformlar vb. aracılığıyla topluma sorularak görüşleri alınabilir. Bu sayede subjektif olmaktan da uzaklaşılabilir ve toplum için yapılan çalışmalara, kentlinin katılımının sağlanması, kenti sahiplenme bilinci oluşturmakta faydalı olacaktır. 
- Mimari estetik komisyonlarının işlevselliğinin yeni yapılacak kent içi köprülerde doğru tasarımın bir parçası olan estetiğin başarılı bir şekilde uygulanabilirliği açısından ne kadar önemli olduğu anlaşılmıştir.

- Yönetmeliklere ve yasalara estetik değerlerle ilgili kuralların eklenmesinin ivedilikle yapılması gereken bir işlem olduğu ve yapılan bu çalışmanın konuya dikkat çekilmesinde katkı sağlayacağı düşünülmektedir.

\section{Notlar}

${ }^{1}$ İlk olarak Planlı Alanlar Tip İmar Yönetmeliği başlığı altında 02.11.1985 yılında yürürlüğe girmiştir.

${ }^{2}$ Plan düzleminde eğrisel çizgi üzerinde kurgulanmış köprülere "Kurbta Köprü" denilmektedir. Harita Mühendisliği bilim dalında "Kurba" olarak da geçmektedir. 


\section{Extended Abctract}

\section{Aesthetic Review of Urban Bridges in Istanbul}

\author{
Ferhat Pakdamar \\ Gebze Technical University \\ ORCID-0000-0002-5594-3095
}

\author{
Cahide Aydın İpekçi \\ Gebze Technical University \\ ORCID-0000-0003-3170-4628
}

Today, among the major problems of the Istanbul metropolis, which is one of the biggest cities of Europe in terms of population, there is the traffic problem caused by rapid, unplanned urbanization, urban development plans and irregularities of the transportation plans in connection with the migration. However, the current car ownership rate in Istanbul is increasing day by day. This will require the existing road network to be increased in parallel with the increasing automobile dependence. It means that the number of urban bridges will increase in addition to the roads to meet the increasing demand for motor vehicles and traffic in Istanbul, which has a similar tendency to transportation trends around the world.

For this reason, in this study in which we discussed the problems observed in the bridge applications used by pedestrian and vehicle (overpass, underpass) in Istanbul, which is selected as the sample area, it is aimed to draw attention to the necessity of a "bridge regulation" in which aesthetic elements will be included. In addition, with this study it is also aimed to show the importance of making the aesthetic commissions operational. Within this context, the phase of studying the problems seen in the urban bridges discussed in this study is significant for designing and planning the construction of new bridges which are part of the urban landscape.

In the study firstly, the definition of bridge, the development of the bridge as a linguistic and historical process are briefly mentioned. Then, the development and change in urban bridges are studied based on examples in relation to materials, construction techniques and design examples, 
and the factors affecting the aesthetic problems are determined. The most essential factor that gives a bridge its shape is its carrier system selected to provide the possibility to cross over an opening. In arranging the correct proportions of the elements that form the structural system, giving attention to their conformity with the environment and their placement in the landscape is important in providing an aesthetic form to the bridges. In addition to the bridge form, materials, colors, paints, textures, decorative elements and safety elements that are used are bridge components that shouldn't be neglected during the design process. However, in our country there is no "bridge regulation" present that can be taken into account or that can be followed during bridge applications, except for a small booklet including very limited information entitled "Technical Specification for Road Bridges" published in 1982 by General Directorate of Highways (KGM). Therefore, for the bridges that are constructed until today, public institutions requested designers to provide solutions in accordance with the American Bridge Regulations (AASHTO). Even though the American Bridge Regulations is one of the best available regulations because of its inadequate sanctions on aesthetics, in 2012 "2.5.5. Bridge Aesthetics" article is added under the Design Targets Section in relation to aesthetics within the AASHTO as a result of the "Bridge Aesthetics Sourcebook" study that is started in 2009. In addition there is a very nice bridge aesthetic guideline regulation that is created for New South Wales region of Australia entitled "Design guidelines to improve the appearance of bridges in NSW".

The study is limited with bridges which system material is reinforced concrete, situated on İstanbul D100, 2nd highway and access roads. The 17 samples selected as a result of the field study are examined separately based on the photos, within the context of bridge aesthetics. The details of the samples selected among the many bridges examined are presented in the table and the aesthetic defects observed in each of them are explained in detail together with the photographs and the inferences are summarized as a conclusion.

Conclusion;

- From the samples examined in between 1969-2017; it is determined that the aesthetic elements applied in the bridges and thus the aesthetic design concern changed inversely with time and that the negative qualities increased. 
- It is understood that the most elegant urban bridges in the sample area are those constructed in between 1969-1980.

- The fact that we don't see elegant bridges in the latest applications is an indicator that the aesthetic problem is left to the engineer, architect and administration's initiative and that there are no laws or rules foreseeing an aesthetic enforcement.

- As there are no legal enforcements and an aesthetic commission in bridge applications, it is seen that they are considered primarily under safety and economy conditions and that a design that definitely ignores the aesthetic elements and values such as aesthetic and ecology is getting widespread.

- It is determined that there is no aesthetic enforcement in the current regulations and that even in the American Bridge Regulation which is considered as the best regulation on this subject, there is only a small section reserved for it.

- It is understood that the appearance of the publicity posters hanging on the bridges (determination of the design and colors) should be evaluated and that the approval of an aesthetic commission that would evaluate their effect on the city's silhouette, should be sought.

- It is determined that it would be appropriate to apply for the aesthetic commission's approval in relation to every application such as advertising boards and posters as well as lighting and drainage systems, that would affect the silhouette of the bridge and its surrounding.

- As another option the alternatives that receive the aesthetic commission's approval can be directed to the society through questionnaires, digital platforms etc. and their opinion can be sought. This way, being subjective can also be avoided. And within this context, this will be beneficial in ensuring the participation of the citizens in the studies realized for the benefit of the society and in creating a consciousness of ownership for the city.

\section{Kaynakça/References}

AASHTO. (2014). AASHTO-LRFD bridge design specification. Washington, DC: American Association of State Highway and Transportation Officials.

Akı, M. ve Öztaş, Ç. Ç. (2015). İstanbul'un geleceği için sürdürülebilir ve çevre dostu ulaşım aracı: Bisiklet. YAPI Dergisi, 401, 52-56. 
Assmann, J., ve Tekin, A. (2001). Kültürel bellek / Eski yüksek kültürlerde yazı, hatırlama ve politik kimlik. İstanbul: Ayrıntı Yayınları.

Avcıoğlu, S. S., ve Akın, O. (2017). Kolektif bellek ve kentsel mekan alg1sı bağlamında İstanbul Tuzla Köyiçi Koruma Bölgesi'nin mekansal değişiminin irdelenmesi. IDEALKENT, 8(22), 423-450.

Başdoğan, S., ve Manisa, K. (2016). Kent merkezinde alternatif kamusal alan arayışı, Jean-Jacques Bosc Köprüsü örneği. YAPI Dergisi, 412, 56-62.

Binan, C. (2006). Anadolu'da ulaşım ve konaklama yapıları bağlamında mimarlık, malzeme ve yapı üretimi üzerine yorumlar. Geçmişten gelecĕ̆ge Anadolu'da malzeme ve mimarlı, sempozyum / UIA 2005 XXIII. Dünya Mimarlık Kongresi (s. 179-210). İstanbul: Mimarlar Odası İstanbul Büyükkent Şubesi.

Bridge Aesthetics. (2003). Design guideline to improve the appearance of bridges in NSW. New South Wales: NSW Roads and Maritime Services.

Erkartal, P. Ö. (2016). Kentsel koruma ve rekonstrüksiyon: Münster Prinzipalmarkt örneği. İDEALKENT, 7(19), 498-526.

Halbwachs, M. (1992). On collective memory. Chicago, U.S.: University of Chicago Press.

Hasol, D. (Der.) (1995) Ansiklopedik mimarlık sözlüğ̈̈ (6. ed.). İstanbul: YEM Yayınevi.

Planlı Alanlar İmar Yönetmeliği.(Temmuz 3, 2017). Resmi Gazete. (Sayı: 30113).

Sourcebook, B. A. (2010). Practical ideas for short and medium span bridges. Washington, DC: American Association of State Highway and Transportation Officials.

Sütiçen, M. (2008). Ülkemizde şehiriçi yaya köprülerinde malzeme kullanımı ve detay sorunları. Yüksek Lisans Tezi, Selçuk Üniversitesi, Konya.

Şahin, K. (1983). Köprü/üst-geçit. Mimarlık, 189(3), 10-12.

Türkçü, Ç. (1997). Çekmeye çalışan taşıyıcı sistemler. İzmir: Eylül Yayınları.

Ünal, A. (2017). Planlı alanlar imar yönetmeliği neler getiriyor? Illler ve Belediyeler, Türkiye Belediyeler Birliği Dergisi, 831, 23-32.

Dr. Öğr. Ü. Ferhat PAKDAMAR doktorasını İstanbul Teknik Üniversitesinden alan Pakdamar aslen inşaat mühendisi olmakla birlikte Gebze Teknik Üniversitesi Mimarlık Bölümü Öğretim Üyeliği ve Mimarlık Fakültesi Dekan Yardımcılığı görevini sürdürmektedir. Akademisyen olmadan önce İstanbul ve civarındaki köprü ve viyadüklerin deprem hesapları ve incelenmesi projelerinde çalışmıştır. Pek çok tarihi yapı restorasyon proje ekibinde bulunmuştur. Bunların yanında Bulanık Mantık ve yapay zeka teknikleri konuları da doktora ilgi alanıdır.

Asst. Prof. Dr. Ferhat PAKDAMAR got his Ph.D. degree from İstanbul Technical University, Pakdamar is a civil engineer, and he is a member of Department of Architecture of the Gebze Technical University and vice dean of Faculty of Architecture. Before he became an academician, he 
worked on seismic retrofit and investigation projects of bridges and viaducts around Istanbul. He also was in many historical buildings' restoration project team. In addition to these, Fuzzy Logic and artificial intelligence techniques are also interest of doctoral areas.

E-mail: pakdamar@gtu.edu.tr

Doç. Dr. Cahide AYDIN İPEKÇİ 1995 yılında Anadolu Üniversitesi Mimarlık Bölümü'nden lisans, 1998 yılında İstanbul Teknik Üniversitesi Yapı Bilimleri Programı'ndan yüksek lisans ve 2009 yılında Yıldız Teknik Üniversitesi Yapı Bilimleri Programı'ndan doktora derecesi almıştır. 1995-1997 yılları arasında serbest mimarlık faaliyetlerinde bulundu. 1997 yılında Anadolu Üniversitesi Mimarlık Bölümü' nde çalışmaya başladı. 1999-2006 yılları arasında Uludağ Üniversitesi Mimarlık Bölümü ve Başkent Üniversitesi İç Mimarlık Bölümü'nde, 2009-2014 yılları arası Gebze Yüksek Teknoloji Enstitüsü Mimarlık Bölümü'nde çalıştı. Halen Gebze Teknik Üniversitesi Mimarlık Bölümü'nde öğretim üyesi olarak görevini sürdürmektedir. Başlıca araştırma alanları arasında yapı malzemeleri, sürdürülebilirlik (yapı malzemelerinin geri kazanımı, yeniden kullanım ve geri dönüşümü), yapı elemanları, taşıyıcı sistem konuları yer almaktadır.

Assoc. Prof. Dr. Cahide AYDIN IPEKÇİ graduated from Anadolu University Faculty of Engineering and Architecture, Department of Architecture in 1995. She got her Master of Science degree from Building Sicence Programme at İstanbul Technical University in 1998 and she got her PhD degree from Building Science Programme at Y1ldız Technical University in 2009. Between 1995-1997 she worked as an independent architect. In 1997, she began working in the Department of Architecture at Anadolu University. She worked at Uludağ University Department of Architecture and Başkent University Department of Interior Design between 19992006, and the Department of Architecture at Gebze Institude of Technology between 2009-2014. She is still working at Gebze Technical University as a member of Department of Architecture. Her main research interests include building materials, sustainability (building materials and recovering, reuse and recycling), building elements, structural system.

E-mail: caipekci@gtu.edu.tr 